\title{
FAKTOR-FAKTOR YANG MEMENGARUHI PENGHINDARAN PAJAK PADA PERUSAHAAN MANUFAKTUR DI BURSA EFEK INDONESIA
}

\author{
DEANNA PUSPITA \\ MEIRISKA FEBRIANTI \\ STIE Trisakti \\ deannapuspita@gmail.com
}

\begin{abstract}
The purpose of this research is to examine the influence of firm size, return on asset, leverage, capital intensity, sales growth and composition of the independent board to tax avoidance. The population of this research is all manufactured companies listed in Indonesia Stock Exchange from 2012 to 2014. Samples are obtained through purposive sampling method, in which only 52 of listed manufactured companies in Indonesia Stock Exchange meet the sampling criterias resulting 156 data available are taken as the samples. The research resource are taken from Indonesia Stock Exchange website. This research used multiple regression method to test the effect of each variable in influencing tax avoidance. The empirical result indicates that firm size, return on asset and sales growth have influence to tax avoidance. However leverage, capital intensity and composition of the independent board have no influence to tax avoidance.
\end{abstract}

Keywords: Tax Avoidance, Firm Size, Return on Asset, Leverage.

\begin{abstract}
Abstrak: Tujuan penelitian adalah untuk menguji pengaruh ukuran perusahaan, return on asset, leverage, intensitas modal, sales growth dan komposisi komisaris independen terhadap penghindaran pajak. Populasi penelitian ini adalah seluruh perusahaan manufaktur yang terdaftar di Bursa Efek Indonesia selama periode 2012 sampai 2014. Sampel penelitian ini diperoleh dengan menggunakan purposive sampling method, dimana hanya 52 perusahaan manufaktur yang terdaftar di Bursa Efek Indonesia memenuhi semua kriteria, sehingga didapat 156 data yang digunakan sebagai sampel penelitian. Sumber data pada penelitian ini diperoleh dari website Bursa Efek Indonesia. Penelitian ini menggunakan model regresi berganda untuk menguji pengaruh masing-masing variabel terhadap penghindaran pajak. Bukti empiris menunjukkan bahwa ukuran perusahaan, return on asset dan sales growth memiliki pengaruh terhadap penghindaran pajak. Sedangkan leverage, intensitas modal dan komposisi komisaris independen tidak memiliki pengaruh terhadap penghindaran pajak.
\end{abstract}

Kata kunci: Penghindaran Pajak, Ukuran Perusahaan, Return on Asset, Leverage. 


\section{PENDAHULUAN}

Pajak merupakan salah satu sumber pendapatan negara yang terbesar. Dimana $76,94 \%$ dari total pendapatan negara berasal dari pendapatan pajak. Hal ini terlihat dari pendapatan pajak sebesar 1.380 triliun rupiah dari total pendapatan negara yaitu 1.793,6 triliun rupiah dalam APBN 2015 (www.fiskal.depkeu.go.id). Penerimaan tersebut digunakan untuk mendukung dan melaksanakan kegiatan pembangunan nasional agar dapat berjalan dengan baik demi mensejahterahkan kehidupan seluruh rakyat Indonesia. Karena peran pajak sangat besar bagi negara, pemerin-tah berupaya untuk meningkatkan penerimaan dari sektor pajak.

Ketika dalam praktik kehidupan nyata, perusahaan cenderung berupaya untuk meminimalkan segala biaya usaha perusahaannya, termasuk beban pajak dengan berbagai cara. Bagi perusahaan, dengan adanya beban pajak maka akan mengurangi bagian laba yang seharusnya dibagikan kepada pihak manajemen dan pemilik modal perusahaan. Oleh karena itu, manajer akan berupaya semaksimal mungkin untuk meminimalkan beban pajak baik dengan cara memanfaatkan kelemahan ketentuan perpajakan maupun dengan cara yang lainnya. Sedangkan bagi negara, pajak sebagai sumber pembiayaan bagi kegiatan negara. Apabila sumber dana tidak mencukupi, maka kegiatan operasional negara otomatis dapat terganggu. Perbedaan kepentingan antara perusahaan dan pemerintah tersebut mengharuskan pemerintah lebih harus memperketat pengumpulan dana dari masyarakat agar tujuan negara dalam mencapai kesejahteraan masyarakat dapat berjalan dengan lancar dan sesuai harapan.

Usaha pengurangan (penghematan) pajak dapat dilakukan dengan berbagai cara misalnya dengan cara penggelapan pajak (tax evasion) dan penghindaran pajak (tax avoidance). Penggelapan pajak (tax evasion) merupakan usaha yang dilakukan oleh perusahaan untuk mengurangi pajak dengan melanggar peraturan perpajakan yang berlaku. Penghindaran pajak (tax avoidance) yaitu upaya penghindaran pajak secara legal yang tidak melanggar peraturan perpajakan untuk meminimalkan beban pajak dengan memanfaatkan kelemahan ketentuan perpajakan. Misalnya melaporkan pendapatan bersih lebih kecil dari yang sebenarnya. Tax avoidance dianggap tidak melanggar peraturan perpajakan dan suatu tindakan yang legal karena perusahaan hanya memanfaatkan kelemahan dalam undang-undang perpajakan.

Penelitian ini dimotivasi dengan banyaknya perusahaan-perusahaan yang melakukan tindakan penghindaran pajak. Misalnya perusahaan di Indonesia yang pernah melakukannya adalah Bank BCA dan perusahaan-perusahaan ternama lain di luar negeri yaitu Apple Inc, Starbucks dan Facebook. Oleh karena itu, peneliti ingin meneliti lebih lanjut mengenai pengaruh ukuran perusahaan, return on asset, leverage, intensitas modal, sales growth dan komposisi komisaris independen.

\section{Penghindaran Pajak}

Pajak dipandang sebagai sesuatu yang tidak menguntungkan bagi perusahaan. Sesuatu yang tidak menguntungkan ini biasanya mendorong adanya upaya untuk melakukan penghindaran atau perlawanan pajak. Tindakan penyelewengan dan penghindaran merupakan salah satu bentuk dari perlawanan terhadap pajak. menghindari pajak (Mulyani et al.). Untuk meminimumkan kewajiban pajak dapat dilakukan dengan berbagai cara, baik yang masih memenuhi ketentuan perpajakan (lawful) maupun yang melanggar peraturan perpajakan (unlawful). Istilah yang sering digunakan adalah tax avoidance dan tax evasion.

Penghindaran pajak adalah rekayasa 'tax affairs' yang masih tetap berada dalam bingkai ketentuan perpajakan (lawful). Menurut Mardiasmo dalam Prakosa (2014), penghindaran pajak adalah suatu usaha meringankan beban pajak dengan tidak melanggar undang-undang yang ada. 


\section{Ukuran Perusahaan}

Ukuran perusahaan merupakan suatu skala yang menggambarkan besar kecilnya suatu perusahaan yang ditunjukkan oleh total aktiva, jumlah penjualan, rata-rata total penjualan dan rata-rata total aktiva. Pada umumnya, perusahaan dibagi menjadi 3 kategori yaitu perusahaan besar, perusahaan sedang dan perusahaan kecil.

Besar kecilnya (ukuran) perusahaan akan berpengaruh terhadap struktur modal dengan didasarkan pada kenyataan bahwa semakin besar suatu perusahaan mempunyai tingkat pertumbuhan penjualan yang tinggi sehingga perusahaan tersebut akan lebih berani mengeluarkan saham baru dan kecenderungan untuk menggunakan jumlah pinjaman juga semakin besar pula. Perusahaan dengan skala kecil lebih fleksibel dalam menghadapi ketidakpastian, karena perusahaan kecil lebih cepat bereaksi terhadap perubahan yang mendadak. Oleh karena itu, memungkinkan perusahaan besar tingkat leveragenya akan lebih besar dari perusahaan yang berukuran kecil.

\section{Return on Asset}

Return on Assets (ROA) berguna untuk mengukur sejauh mana efektivitas perusahaan dalam memanfaatkan seluruh sumber daya yang dimilikinya. Return on Assets (ROA) adalah suatu indikator yang mencerminkan performa keuangan perusahaan, semakin tingginya nilai ROA yang mampu diraih oleh perusahaan maka performa keuangan perusahaan tersebut dapat dikategorikan baik (Maharani dan Suardana, 2014). Semakin tinggi profitabilitas perusahaan maka akan semakin tinggi pula laba bersih yang dihasilkan oleh perusahaan. Semakin tinggi profitabilitas maka perencanaan perusahaan akan semakin matang pula sehingga dapat menghasilkan pajak yang optimal pula.

\section{Leverage}

Leverage merupakan rasio untuk mengukur seberapa jauh perusahaan menggunakan utang untuk membiayai investasi. Leverage diukur dengan menggunakan rasio debt to equity ratio (DER). Debt to equity ratio (DER) merupakan perbandingan antara total hutang dengan total ekuitas perusahaan sebagai sumber pendanaan. Perusahaan yang menggunakan hutang pada komposisi pembiayaan maka akan menimbulkan adanya beban bunga yang harus dibayar. Beban bunga merupakan biaya yang dapat dikurangkan (deductible expense) terhadap penghasilan kena pajak sehingga menyebabkan laba kena pajak perusahaan menjadi berkurang dan pada akhirnya akan mengurangi jumlah pajak yang harus dibayar oleh perusahaan. Apabila perusahaan menggunakan equity financing dalam pembiayaan perusahaan maka harus membayar dividen yang dimana dividen tidak dapat dijadikan pengurang penghasilan kena pajak.

\section{Intensitas Modal}

Intensitas modal mencerminkan seberapa besar modal yang dibutuhkan perusahaan untuk menghasilkan pendapatan yang diperoleh dari penurunan aktiva tetap atau peningkatan aktiva tetap. Intensitas modal didefinisikan sebagai rasio antara aktiva tetap seperti peralatan, mesin dan berbagai properti terhadap total aktiva (Noor et al., 2010:190 dalam Mulyani et al.). Pemanfaatan pengurangan perpajakan dapat dilakukan perusahaan yang memilih investasi dalam bentuk aset ataupun modal dalam hal depresiasi. Perusahaan yang berinvestasi dalam bentuk aset tetap dapat menjadikan biaya depresiasi sebagai biaya yang dapat dikurangkan dan pada akhirnya dapat mengurangi jumlah pajak yang harus dibayar perusahaan.

\section{Sales Growth}

Tingkat pertumbuhan perusahaan dapat diukur dengan berbagai macam indikator, misalnya pertumbuhan penjualan, aset, harga saham. Apabila indikator yang digunakan itu menghasilkan nilai yang tinggi maka dapat diartikan bahwa perusahaan sedang bertumbuh pesat dan laba yang dihasilkan oleh perusahaan juga akan mengalami kenaikan. Kenaikan laba tersebut 
berarti penghasilan kena pajak yang dihasilkan perusahaan semakin besar. Pada penelitian kali ini, indikator yang digunakan oleh peneliti adalah pertumbuhan penjualan (sales growth). Pertumbuhan penjualan menunjukkan perkembangan dari penjualan perusahaan dari tahun ke tahun.

\section{Komposisi Komisaris Independen}

Komposisi komisaris independen adalah persentase perbandingan antara komisaris independen dengan jumlah anggota dewan komisaris lainnya yang memegang peranan dalam pengawasan manajemen perusahaan (Dewi dan Jati, 2014). Komisaris independen dapat melaksanakan fungsi monitoring untuk mendukung pengelolaan perusahaan yang baik dan menjadikan laporan keuangan lebih objektif (Kurniasih dan Sari, 2013).

Komposisi komisaris dapat memberikan kontribusi yang efektif terhadap hasil dari proses penyusunan laporan keuangan yang berkualitas atau kemungkinan terhindar dari kecurangan laporan keuangan. Sehingga dapat dikatakan bahwa komposisi komisaris independen mempunyai kecenderungan mempengaruhi manajemen laba.
Berdasarkan kerangka teoretis, peneliti mengemukakan hipotesis penelitian sebagai berikut :

$\mathrm{H} 1 \quad$ Ukuran perusahaan berpengaruh terhadap penghindaran pajak.

$\mathrm{H} 2$ Return on asset (ROA) berpengaruh terhadap penghindaran pajak.

H3 Leverage berpengaruh terhadap penghindaran pajak.

H4 Intensitas modal berpengaruh terhadap penghindaran pajak.

H5 Sales growth berpengaruh terhadap penghindaran pajak.

H6 Komposisi komisaris independen berpengaruh terhadap penghindaran pajak.

\section{METODE PENELITIAN}

Populasi yang digunakan dalam penelitian ini adalah perusahaan manufaktur yang terdaftar di Bursa Efek Indonesia. Obyek pengamatan menggunakan tahun penelitian 2012 sampai 2014. Sampel diambil dengan menggunakan metode purposive sampling, dimana setiap sampel yang diambil harus memenuhi kriteria tertentu. Kriteria yang harus dipenuhi antara lain:

Tabel 1. Kriteria Pemilihan Sampel

\begin{tabular}{lcc}
\hline \multicolumn{1}{c}{ Kriteria Sampel } & $\begin{array}{c}\text { Jumlah Sampel } \\
\text { per Tahun }\end{array}$ & Total Sampel \\
\hline 1. Perusahaan manufaktur yang terdaftar di Bursa Efek & 127 & 381 \\
Indonesia sejak tahun 2012 sampai dengan 2014 & & \\
2. Perusahaan dengan data yang tidak lengkap & $(0)$ & $(0)$ \\
3. Perusahaan yang tidak menerbitkan laporan keuangan & $(4)$ & $(12)$ \\
auditan setiap tanggal 31 Desember & & \\
4. Perusahaan yang tidak menerbitkan laporan keuangan & $(26)$ & $(78)$ \\
dalam mata uang rupiah & & $(33)$ \\
5. Perusahaan dengan nilai laba negatif & $(12)$ & $(36)$ \\
6. Perusahaan dengan nilai CETR $>1$ & 52 & 156 \\
Total data sebelum outlier & & $(1)$ \\
Data outlier & & 155 \\
Total data setelah outlier yang digunakan dalam penelitian & & \\
\hline
\end{tabular}


Penghindaran pajak adalah upaya untuk mengurangi atau bahkan meniadakan hutang pajak yang harus dibayar oleh perusahaan dengan tidak melanggar peraturan undang-undang yang ada. Pengukuran penghindaran pajak dalam penelitian ini menggunakan model Cash Effective Tax Rates (CETR) yaitu kas yang dikeluarkan untuk biaya pajak dibagi dengan laba sebelum pajak. Nilai Cash Effective Tax Rate yang digunakan adalah yang memiliki nilai dibawah 1. Adapun rumus untuk menghitung Cash Effective Tax Rates (CETR) adalah sebagai berikut:

$$
C E T R=\frac{\text { Pembayaran Pajak }}{\text { Laba Sebelum Pajak }}
$$

Ukuran perusahaan merupakan gambaran dari besar kecilnya suatu perusahaan. Ukuran perusahaan adalah ukuran atau besarnya aset yang dimiliki oleh perusahaan tersebut. Ukuran perusahaan (size) yang ditunjukkan melalui log total aktiva, dinilai lebih baik karena ukuran perusahaan ini memiliki tingkat kestabilan yang lebih dibandingkan proksi-proksi yang lainnya dan cenderung berkesinambungan antar periode satu dengan periode berikutnya (Jogiyanto, 2000 dalam Prakosa, 2014). Ukuran perusahaan (size), diukur dengan menggunakan natural logarithm total assets (Guire et al, 2011 dalam Prakosa, 2014). Adapun rumus untuk menghitung ukuran perusahaan yaitu sebagai berikut:

$$
\text { SIZE }=\text { Ln(Total Asset) }
$$

Return on Asset (ROA) merupakan perbandingan antara laba bersih dengan total aset pada akhir periode, yang digunakan sebagai indikator dari kemampuan perusahaan dalam menghasilkan laba (Kurniasih dan Sari, 2013). Adapun rumus untuk menghitung return on asset (ROA) yaitu sebagai berikut:

$$
R O A=\frac{\text { Laba Bersih Setelah Pajak }}{\text { Total Asset }} \times 100 \%
$$

Leverage adalah rasio yang mengukur kemampuan utang baik jangka panjang maupun jangka pendek untuk membiayai aktiva perusahaan (Kurniasih dan Sari, 2013). Leverage dapat diukur dengan menggunakan rasio total debt to equity ratio. Adapun rumus untuk menghitung leverage yaitu sebagai berikut:

Debt to Equity Ratio $=\frac{\text { Total Liabilities }}{\text { Total Ekuitas }}$

Intensitas modal mencerminkan seberapa besar modal yang dibutuhkan untuk menghasilkan pendapatan. Dalam melakukan investasi, perusahaan harus selalu mempertimbangkan setiap peluang dalam memperebutkan pasar. Indikator prospek perusahaan dimasa depan dapat dilihat dari sisi intensitas modal. Intensitas modal menggambarkan rasio antara aktiva tetap seperti peralatan, mesin dan berbagai properti lain terhadap total aktiva. Adapun rumus untuk menghitung intensitas modal yaitu:

$$
\text { Capint }=\frac{\text { Total aktiva tetap }}{\text { total asset }}
$$

Pertumbuhan perusahaan pada penelitian ini diukur dari pertumbuhan penjualannya (sales growth). Pertumbuhan penjualan (sales growth) menunjukkan perkembangan tingkat penjualan perusahaan dari tahun ke tahun. Oleh karena itu, suatu perkembangan bisa meningkat ataupun menurun. Pertumbuhan penjualan diukur dengan cara penjualan akhir periode dikurangi dengan penjualan awal periode dibagi dengan penjualan awal periode (Brad Badertscher et al, 2009 dalam Budiman dan Setiyono 2012). Adapun rumus untuk menghitung sales growth yaitu sebagai berikut:

$$
\text { Sales Growth }=\frac{\text { Penjualan Akhir Periode }- \text { Penjualan Awal Periode }}{\text { Penjualan Awal Periode }}
$$

Komposisi komisaris independen diukur menggunakan persentase dewan komisaris independen terhadap jumlah total dewan komisaris 
yang mempunyai peranan dalam pengawasan manajemen perusahaan. Adapun rumus untuk menghitung komposisi dewan komisaris independen yaitu sebagai berikut: Komposisi Komisaris Independen $=\frac{\text { jumlah komisaris independen }}{\text { jumlah komisaris perusahaan }} X 100 \%$

\section{HASIL PENELITIAN}

Statistik deskriptif memberikan gambaran data yang dilihat dari nilai rata-rata, standar deviasi, minimum dan maksimum. Hasil dari pengolahan statistik deskriptif adalah sebagai berikut

Tabel 2 Hasil Pengolahan Statistik Deskriptif

\begin{tabular}{lcrrrc}
\hline \multicolumn{1}{c}{ Variabel } & N & Minimum & Maximum & Mean & Std. Deviation \\
\hline CETR & 156 & 0,000626 & 0,966775 & 0,297819 & 0,145555 \\
SIZE & 156 & 25,276680 & 33,094975 & 28,232792 & 1,821409 \\
ROA & 156 & 0,000899 & 0,403768 & 0,109509 & 0,087016 \\
DER & 156 & 0,079293 & 5,152419 & 0,774679 & 0,731082 \\
CAPINT & 156 & 0,045770 & 0,843149 & 0,336632 & 0,185933 \\
SALES GROWTH & 156 & $-0,267460$ & 1,253526 & 0,144594 & 0,160217 \\
KOM & 156 & 0,000000 & 1,000000 & 0,361461 & 0,149008 \\
\hline
\end{tabular}

Sumber: Pengolahan data SPSS 19

Hasil pengujian hipotesis dapat dilihat pada tabel 3 berikut ini :

Tabel 3 Hasil Pengujian Hipotesis

\begin{tabular}{lccl}
\hline \multicolumn{1}{c}{ Variabel } & Koefisien & Sig. & \multicolumn{1}{c}{ Kesimpulan } \\
\hline (Constant) & $-0,061$ & 0,703 & Tidak berpengaruh \\
SIZE & 0,015 & 0,012 & Berpengaruh \\
ROA & $-0,401$ & 0,001 & Berpengaruh \\
DER & 0,013 & 0,341 & Tidak berpengaruh \\
CAPINT & $-0,042$ & 0,473 & Tidak berpengaruh \\
SALES GROWTH & $-0,220$ & 0,001 & Berpengaruh \\
KOM & 0,039 & 0,567 & Tidak berpengaruh \\
\hline
\end{tabular}

Sumber : Pengolahan data SPSS 19

Dari hasil uji t, maka model regresi dari penelitian ini adalah:

CETR $=-0,061+0,015$ SIZE $-0,401 \mathrm{ROA}+$ 0,013 DER - 0,042 CAPINT - 0,220 sales growth $+0,039 \mathrm{KOM}$. Dimana nilai constant menunjukkan angka -0,061, artinya variabel dependen yaitu penghindaran pajak sama dengan -0,061 dengan asumsi jika nilai dari variabel independen ukuran perusahaan, return on asset, leverage, intensitas modal, sales growth dan komposisi komisaris independen sama dengan nol. 
Hasil uji t menunjukkan bahwa variabel ukuran perusahaan (SIZE) memiliki nilai koefisien sebesar 0,015. Hal ini berarti bahwa setiap kenaikan ukuran perusahaan satu-satuan, maka variabel penghindaran pajak akan naik sebesar 0,015 dengan asumsi bahwa variabel bebas yang lain dari model regresi adalah tetap. Variabel ukuran perusahaan (SIZE) memiliki nilai signifikansi 0,012 lebih kecil dari alpha 0,05. Artinya variabel ukuran perusahaan memiliki pengaruh terhadap variabel penghindaran pajak. Hasil penelitian ini menerima hasil hipotesis pertama $\left(\mathrm{Ha}_{1}\right)$ yang menyatakan bahwa ukuran perusahaan berpengaruh terhadap penghindaran pajak. Pengambilan keputusan mengenai jenis pendanaan yang akan diambil oleh perusahaan bergantung pada besar kecilnya (ukuran) perusahaan. Semakin besar suatu perusahaan maka perusahaan tersebut akan lebih berani untuk menggunakan pinjaman yang semakin besar pula. Sedangkan perusahaan kecil lebih cepat bereaksi terhadap perubahan yang mendadak. Oleh karena itu, tingkat leverage perusahaan berukuran besar akan lebih besar dari perusahaan yang berukuran kecil.

Hasil uji t menunjukkan variabel return on asset (ROA) memiliki nilai koefisien sebesar 0,401 . Hal ini berarti bahwa setiap kenaikan return on asset satu-satuan, maka variabel penghindaran pajak akan turun sebesar 0,401 dengan asumsi bahwa variabel bebas yang lain dari model regresi adalah tetap. Variabel return on asset memiliki nilai signifikansi sebesar 0,001 lebih kecil dari 0,05 . Artinya variabel return on asset (ROA) memiliki pengaruh terhadap variabel penghindaran pajak. Hasil penelitian ini menerima hipotesis kedua $\left(\mathrm{Ha}_{2}\right)$ yang menyatakan bahwa return on asset (ROA) berpengaruh terhadap penghindaran pajak. Dalam penelitian ini terlihat bahwa terdapat pengaruh negatif antara return on asset dan penghindaran pajak. Jika return on asset mengalami peningkatan, maka penghindaran pajak akan mengalami penurunan. Return on asset menunjukkan tingkat profitabilitas perusahaan. Dimana profitabilitas merupakan faktor penting dalam pengenaan pajak penghasilan bagi perusahaan karena profitabilitas merupakan indikator perusahaan dalam pencapaian labanya. Semakin tinggi profitabilitas perusahaan, maka semakin matang pula perencanaan pajak yang dilakukan perusahaan. Sehingga menghasilkan pajak yang optimal dan kecenderungan perusahaan untuk melakukan penghindaran pajak pun akan semakin menurun.

Hasil uji t menunjukkan variabel leverage (DER) memiliki nilai koefisien adalah sebesar 0,013 . Hal ini berarti bahwa setiap kenaikan leverage satu-satuan, maka variabel penghindaran pajak akan naik sebesar 0,013 dengan asumsi bahwa variabel bebas yang lain dari model regresi adalah tetap. Variabel leverage memiliki nilai signifikansi sebesar 0,341 dimana angka tersebut lebih besar dari 0,05, maka dapat dikatakan bahwa variabel leverage tidak berpengaruh terhadap variabel penghindaran pajak. Hasil penelitian ini tidak menerima hipotesis ketiga $\left(\mathrm{Ha}_{3}\right)$ yaitu leverage berpengaruh terhadap penghindaran pajak. Ini menunjukkan bahwa semakin tinggi ataupun semakin rendah leverage suatu perusahaan tidak berpengaruh terhadap penghindaran pajak yang dilakukan oleh perusahaan. Keputusan pendanaan perusahaan dapat dijadikan sebagai penghindaran pajak terkait dengan tarif pajak efektif. Keputusan pendanaan adalah keputusan perusahaan untuk menggunakan pendanaan yang berasal dari internal ataupun eksternal. Perusahaan yang menjadi sampel memiliki nilai hutang jangka panjang yang kecil. Oleh karena itu beban bunga dari hutang jangka panjang yang dihasilkan juga rendah sehingga beban bunga tidak dapat memberikan pengaruh yang signifikan terhadap penghindaran pajak.

Hasil uji t menunjukkan bahwa variabel intensitas modal (CAPINT) memiliki nilai koefisien sebesar $-0,042$. Hal ini berarti bahwa setiap kenaikan intensitas modal satu-satuan, maka variabel penghindaran pajak akan turun sebesar 0,042 dengan asumsi bahwa variabel bebas yang lain dari model regresi adalah tetap. Variabel intensitas modal memiliki nilai signifikansi adalah sebesar 0,473 lebih besar dari 
0,05, maka dapat dikatakan bahwa variabel intensitas modal tidak berpengaruh terhadap variabel penghindaran pajak. Hasil penelitian ini tidak menerima hipotesis keempat $\left(\mathrm{Ha}_{4}\right)$ yang menyatakan bahwa intensitas modal berpengaruh terhadap penghindaran pajak. Hal ini disebabkan karena nilai rata-rata intensitas modal perusahaan yang menjadi sampel cukup rendah yaitu sebesar 0,34 . Oleh karena itu, beban penyusutan yang berasal dari aktiva tetap perusahaan tidak berpengaruh besar terhadap pengurangan penghasilan pajak perusahaan.

Hasil uji t menunjukkan bahwa variabel sales growth memiliki nilai koefisien sebesar $-0,220$. Hal ini berarti bahwa setiap kenaikan sales growth satu-satuan, maka variabel penghindaran pajak akan turun sebesar 0,220 dengan asumsi bahwa variabel bebas yang lain dari model regresi adalah tetap. Variabel sales growth memiliki nilai signifikansi sebesar 0,001 lebih kecil dari 0,05 maka dapat dikatakan bahwa variabel sales growth berpengaruh terhadap penghindaran pajak. Hasil penelitian ini menerima hipotesis kelima ( $\left.\mathrm{Ha}_{5}\right)$ yang menyatakan bahwa sales growth berpengaruh terhadap penghindaran pajak. Semakin tinggi pertumbuhan penjualan perusahaan maka besar kemungkinan laba yang dihasilkan perusahaan menjadi besar. Apabila laba yang dihasilkan perusahaan adalah besar, maka perusahaan akan melakukan perencanaan pajak semakin baik pula. Oleh karena itu, kemungkinan perusahaan untuk melakukan tindakan penghindaran pajak akan menjadi rendah.

Hasil uji t menunjukkan bahwa variabel komposisi komisaris independen (KOM) memiliki nilai koefisien sebesar 0,039. Hal ini berarti bahwa setiap kenaikan komposisi komisaris independen satu-satuan, maka variabel penghindaran pajak akan naik sebesar 0,039 dengan asumsi bahwa variabel bebas yang lain dari model regresi adalah tetap. Variabel komposisi komisaris independen memiliki nilai signifikansi sebesar 0,567 lebih besar dari 0,05, maka dapat dikatakan bahwa variabel komposisi komisaris independen tidak berpengaruh terhadap peng- hindaran pajak. Hasil penelitian ini tidak menerima hipotesis keenam $\left(\mathrm{Ha}_{6}\right)$ yang menyatakan bahwa komposisi komisaris independen berpengaruh terhadap penghindaran pajak. Hal ini memberikan bukti bahwa selama periode pengamatan ada kecenderungan bahwa semakin besar rasio komisaris independen maka tidak memengaruhi tindakan penghindaran pajak yang terjadi di perusahaan. Nilai rata-rata komposisi komisaris independen yang dimiliki perusahaan sampel sebesar 36,15\%. Hal ini menjelaskan bahwa perusahaan telah mematuhi perundang-undangan Perseroan Terbatas No.40 tahun 2007 dan peraturan BAPEPAM No.IX.1.5 tahun 2004 dan peraturan BEJ No $1 \mathrm{~A}$ tahun 2004, yang menyatakan bahwa perusahaan yang sahamnya terdaftar di BEI harus memiliki sekurang-kurangnya 30\% Dewan Komisaris Independen dari seluruh anggota Dewan Komisaris. Semakin banyak jumlah komisaris independen maka semakin besar pengaruhnya untuk mengawasi kinerja manajemen. Maka keputusan untuk melakukan penghindaran pajak akan menurun, tetapi pengawasan internal secara langsung cukup sulit memengaruhi penghindaran pajak yang dilakukan perusahaan. Hal ini dikarenakan komisaris independen hanya dapat mengawasi kinerja manajemen tetapi yang mengambil keputusan tetaplah manajemen itu sendiri. Wewenang komisaris independen tidak dapat secara langsung mengurangi keinginan manajemen untuk melakukan penghindaran pajak.

\section{PENUTUP}

Berdasarkan hasil pengujian hipotesis, dapat disimpulkan bahwa variabel ukuran perusahaan, return on asset dan sales growth berpengaruh terhadap penghindaran pajak perusahaan. Sedangkan variabel leverage, intensitas modal dan komposisi komisaris independen tidak berpengaruh terhadap penghindaran pajak.

Keterbatasan dalam penelitian ini adalah penelitian ini hanya mengambil jangka waktu 3 tahun, yaitu periode 2012 -2014, penelitian 
hanya menggunakan objek penelitian pada perusahaan manufaktur yang terdaftar di Bursa Efek Indonesia, sehingga sampel yang dihasilkan sedikit dan penelitian ini hanya menggunakan 6 variabel yang dapat memengaruhi penghindaran pajak perusahaan yaitu ukuran perusahaan, return on asset, leverage, intensitas modal, sales growth dan komposisi komisaris independen. Masih terdapat banyak variabel independen lain yang diduga memengaruhi

\section{REFERENSI :}

Budiman, Judi dan Setiyono. 2012. Pengaruh Karakter Eksekutif terhadap Penghindaran Pajak (Tax Avoidance). Proceeding Simposium Nasional Akuntansi X, Banjarmasin 25-28 September 2012.

Dewi, Ni Nyoman Kristiana Dewi dan I Ketut Jati. 2014. Pengaruh Karakteristik Eksekutif, Karakteristik Perusahaan dan Dimensi Tata Kelola Perusahaan yang baik pada Tax Avoidance di Bursa Efek Indonesia. E-jurnal Akuntansi Universitas Udayana, 249-260,

http://download.portalgaruda.org/article.php?article=143168\&val=986\&title = pengaruh karakter eksekutif, karakteristik perusahaan, dan dimensi tata kelola perusahaan yang baik pada tax avoidance di bursa efek Indonesia.

Ghozali, Imam. 2011. Aplikasi Analisis Multivariate dengan Program IBM SPSS 19. Semarang: Universitas Diponegoro.

Hanlon, Michelle dan Shane Heitzman. 2010. A Review of Tax Research. Journal of Accounting and Economics 50, 127-178.

Kurniasih, Tommy dan Maria M. Ratna Sari. 2013. Pengaruh Return on Assets, Leverage, Corporate Goverance, Ukuran Perusahaan dan Kompensasi Rugi pada Tax Avoidance. Buletin Studi Ekonomi, Vol 18, No.1, 58-66.

Lasmana, Eko J. 2014. Undang-Undang Pajak Lengkap Tahun 2014. Jakarta: Mitra Wacana Media.

Maharani, I Gusti Ayu Cahya dan Ketut Alit Suardana. 2014. Pengaruh Corporate Governance, Profitabilitas dan Karakteristik Eksekutif pada Tax Avoidance Perusahaan Manufaktur. E-jurnal Akuntansi Universitas Udayana, 525-539, http://ojs.unud.ac.id/index.php/Akuntansi/article/view/9290

Mulyani, Sri, Darminto dan M.G Wi Endang N.P. Pengaruh Karakteristik Perusahaan, Koneksi Politik dan Reformasi Perpajakan terhadap Penghindaran Pajak (Studi pada Perusahaan Manufaktur yang Terdaftar di Bursa Efek Tahun 2008-2012).

Prakosa, Kesit Bambang. 2014. Pengaruh Profitabilitas, Kepemilikan Keluarga dan Corporate Governance terhadap Penghindaran Pajak di Indonesia. http://multiparadigma.lecture.ub.ac.id/files/2014/09/100.pdf

Puspita, Silvia Ratih. 2014. Pengaruh Tata Kelola Perusahaan Terhadap Penghindaran Pajak (Studi Terhadap Perusahaan Non-Keuangan yang Terdaftar di Bursa Efek Indonesia Tahun 2010-2012. Skripsi Fakultas Ekonomika dan Bisnis Universitas Diponegoro, Semarang.

Suandy, Erly. 2011. Perencanaan Pajak. Jakarta: Salemba Empat.

Surbakti, Theresa Adelina Victoria. 2012. Pengaruh Karakteristik Perusahaan dan Reformasi Perpajakan Terhadap Penghindaran Pajak di Perusahaan Industri Manufaktur yang Terdaftar di Bursa Efek Indonesia Tahun 2008-2010. Skripsi Jurusan Akuntansi Fakultas Ekonomi Universitas Indonesia, Depok.

Waluyo. 2013. Perpajakan Indonesia. Jakarta: Salemba Empat.

www.fiskal.depkeu.go.id 